\title{
12. Are the Nordic Countries at a Crossroads?
}

Henrik Tham

The question of how the drug policies of the Nordic countries will develop in the near future will be characterized by retreat or entrenchment, by decriminalization or continued penalization, by an increase or a decrease in police resources, and by more or less people in prison, will depend on both the historic development and the present situation. The existing drug policies constitute the starting point, and those policies have been historically created. The histories of the five countries, in terms of their drug policies, show both common and separate traits.

A common characteristic of the countries is the fact that they are all advanced welfare states. A number of features of the drug policies seem to be connected to welfare state ambitions. A clear trait is the tradition of care. No one should be left to her- or himself with serious problems but should be able to count on public help. This is shown by the public health system of all the countries. Even if the problems can be regarded as self-inflicted, a non-moral and social deterministic view would, in principle, characterize the Nordic welfare state.

Such an understanding of individual problems could be regarded as humanistic but also as patriarchal. It has been claimed that welfare states in the Nordic countries act as parents in relation to citizens, showing care but also defining what the problem is and how it should be solved. Such an understanding could lead to a situation where the state doesn't think that the subjects understand their problems properly and therefore need help, which

How to cite this book chapter:

Tham, Henrik. Are the Nordic Countries at a Crossroads?. In: Retreat or Entrenchment? Drug Policies in the Nordic Countries at a Crossroads, edited by Henrik Tham, 293-303. Stockholm: Stockholm University Press, 202I. DOI: https://doi.org/IO.I6993/bbo.l. License: CC BY 4.0. 
sometimes even needs to be provided by force (Smith \& Ugelvik 20I7). The Nordic states have, in varying degrees, employed compulsory care of people with problematic drug use. This side of the caring tradition could possibly lead to administrative sanctions replacing penal sanctions in a situation following decriminalization.

An analysis of the Swedish welfare state summaries the project as 'putting life in order' (Hirdman 2000). The state represents the highest reason. Rules are created for 'how it should be', thereby creating deviants. Critique of state interventions as violations of the private sphere would be countered with the argument that the problems of the individual are degrading and constitute the real violation, rather than the intervention to try to help the citizens (op. cit.: 229, 232). Translated into this context, state interference with drug consumption would be justified as being to the benefit of the drug user.

The Nordic welfare state is part of a strong reformist social democracy. Social democracy is neither libertarian, non-interventionist, minimal state nor revolutionary striving for an entirely different system that is supposed to more or less immediately solve most problems. Its reformist character could even lead to an ambition to create social problems to have something to intervene against. Non-intervention would just seem alien in a welfare state context. The abolitionist demands of decriminalization and legalization of drugs have been difficult to accept for politicians, civil servants and treatment personnel, and possibly also the general public in the Nordic countries.

The reformism of the welfare state can be interpreted as a most ambitious project to wipe out social problems. In an analysis of the drug policy of Sweden it has been claimed that the goal of the policy is 'the clean home' (Gould I994). The Minister of Social Affairs even confirmed this indirectly in a response to this critique (Westerberg I994). This understanding of the drug problem has also been demonstrated in Norway and Iceland by the official mottos of 'a drug free society'. At the same time, however, it should be noted that this expression was directly refuted in Finland and was only recently being used politically in Denmark.

Another historic feature with possible relevance for the present drug policy in the Nordic countries is the tradition from the 
temperance movement. In the first part of the twentieth century, Finland, Iceland and Norway had alcohol prohibition. Sweden had a ration system, limiting the amount of alcohol that could be bought. Denmark, closer to continental culture, did not have these restrictions but tried to regulate alcohol consumption through high taxation. The four northern states clearly belonged to the 'Vodka-belt'. The climate made the growing of grapes for wine or hops for beer difficult. An alcohol culture based on distilled beverages developed, with a drinking pattern with more detrimental effects (Lenke I99I). The heavy drinking led to the formation of strong temperance movements in the later part of the nineteenth century.

Different but connected effects of the tradition from the temperance movements in four of the five countries could possibly be discerned. A central idea of the temperance movements was that weaker alcoholic beverages, beer, would likely lead to binge drinking of aqua vitae. This was the 'stepping stone theory' that inspired an alcohol policy that regarded beer drinking as risky and inappropriate (Lenke I99I). Places for drinking beer were not encouraged. Iceland did not permit beer until I989. The cozy atmosphere of an English pub or a German Bierstube was hardly present in places for beer drinking and would be avoided by most respectable people in some of the countries.

The absolutist organizations in both the field of alcohol and drugs have joined together. The temperance movement has then transferred its traditions to the NGOs working against drugs. The zero-tolerance drug policy corresponds to the strict rule of non-drinking of the teetotalers. The strict stand also results in a resistance to mark a difference between 'soft drugs', beer and cannabis, and 'hard drugs', spirits and heroin. The fight against cannabis also became central in the drug policies, with its use interpreted in the frame of it being a stepping stone requiring early intervention and not sending the right signals.

A possible further effect of the tradition from the temperance movement is a resistance to medical solutions to the drug problem. Solutions should be social rather than biological. This has manifested itself initially in a resistance to syringe exchange and substitution treatment. In the debate in Sweden about a national syringe 
exchange programme, the medical profession was in favour but the personnel in different types of therapeutic treatments were opposed (Tham 2005). The proposal for a national programme was first rejected but later accepted when syringe exchange was attached to treatment interventions.

The forces that have shaped the drug policies in the Nordic countries will still be active when the present policies are analyzed in a situation where several other countries are retreating from the war on drugs. The insight of the objective damage that the consumption of drugs has caused will of course also be present. To sum up, the welfare state, the tradition of the temperance movement and the observed results of heavy drug use all seem to have worked in the direction of a drug policy that will not promote a liberalization.

Whether or not there will be a change in the drug policies of the Nordic countries in a liberal direction will ultimately depend on the governments. Will the ruling parties propose decriminalization, and is there a majority in Parliament for such reforms, and others, in the direction of liberalization of the drug policy? Denmark never went as far as the other countries in criminalizing drug consumption, but the sanctions for drug possession and dealing have, on the other hand, been strengthened. In Finland, both the Government and the political parties are divided on the question of decriminalization, but the Prime Minister and the majority of the Government Ministers are against it. In Iceland, a number of proposals for decriminalization have been presented but have so far been defeated in the Parliament.

In early 202I, the Norwegian Government recommended a decriminalization of the use of drugs and minor possessions for own use to the Parliament. The parties in the Parliament were, however, divided on the issues and the proposal was defeated when the Social Democrats opposed the bill. Finally, the Swedish Social Democratic-Green Government is very clearly against decriminalization, but the Social Democratic youth-party has demanded an evaluation of the criminalization of use of drugs. Some of the parties in Parliament take the same stand and in 2020, the Parliament demanded an evaluation of the Swedish drug policy.

The Police have been, and are, a central actor in the drug policies of the Nordic countries, stressing the importance of penal law, 
police resources and unconventional police measures. In Norway, the Drug Police Association has 'occupied' a large number of internet-sites in order to direct those searching for information to police perspectives. In Denmark, the Police were active in the creation of the 'Pusher law', which increased police powers (Frantzsen 2005). Cases involving possession of illicit drugs have increased markedly in Denmark and likely indicate increased police activity. In Finland, the Police have influenced the penalty scales to allow them the possibility to carry out searches for suspected drug crimes. The special drug police in Iceland, often US-trained, have been quite active in describing the threat from drugs and demanding increased resources and penal law expansions. The Swedish Police wrote their own drug policy manifesto and were quite active in the demand for a legislative change that made the control of body liquid possible (Rikspolisstyrelsen I989; Proposition I987/88:7 I: 88). The Swedish Drug Police Association has also been most active in spreading an alarmistic view on drugs and demanding more control through a journal, conferences, study-trips and collaboration with other similar associations, particularly in the USA (Svenska Narkotikapolisföreningen). How the Police in the different Nordic countries will react to proposals of decriminalization, and even legalization, will be of central importance for the future development of the drug policies.

As said in the introductory chapter, the general criminal policy of the Nordic countries is relatively liberal in an international context, referred to as 'Scandinavian exceptionalism'. The comparatively low prison populations and relatively decent standards of the prisons are still true. All the countries have, however, moved in the direction of a more law and order oriented criminal policy (Lappi-Seppälä 20ı6). In this development, 'organized crime' is increasingly referred to as a serious threat that has to be combatted. The drug trade is pictured to be at the centre of organized crime, and increasingly the demand side is being put forward as the driving force of this.

Finally, an open political and public debate of the risks of using drugs and the costs of controlling drugs seems difficult to establish. In principle, everyone agrees on the importance of an evidence-based drug policy. In the interviews in Sweden with treatment personnel and people undergoing treatment, both sides 
referred to scientific 'facts' but came up with diametrically opposite conclusions. The ideological component of the drug issue seems quite strong. This circumstance has led social scientists to look for other explanations to 'the war on drugs'. Alternative explanations to a rational drug policy have been suggested in terms like 'the good enemy', 'moral panic', 'outsiders' and 'national projects'. The ideological character of the drug issue could, in principle, lead policies in both a more and less restrictive direction. Thus far, however, it seems to primarily have prevented a more open debate on the pros and cons of the present drug policies.

Even though there are different circumstances pointing in the direction of status quo in the drug policies, there are also signs of liberalization and developments that seem to demand a change. That the debate about drug policies has escalated is quite clear in all the countries. One line of critique is the general lack of positive results of the drug policies pursued so far. The groups of problematic drug users have not been shown to be reduced. The situation of marginalized people using drugs has repeatedly been reported as bad or even deteriorating. The living conditions of these groups is a central argument in the Norwegian report on drug policy and its proposal to move from control to help. All the countries have high death tolls that have become increasingly politically disturbing. The Swedish Parliament has demanded zero-tolerance to drug-related deaths. Arguments that the high figures are the result of repressive drug policies are increasingly coming to the fore in the debate.

The tradition from the temperance movement might in this context have the potential of liberalizing policies. Iceland, Finland and Norway gave up on alcohol prohibition. Sweden abandoned the rationing system and reduced alcohol control measures in several respects. The costs of control of prohibition and other regulations became too large and the system was changed. In the present debate, comparisons between alcohol and drug policies are also frequently made in the Nordic countries by those who demand a policy that is less based on punishment.

There is also the market. The analysis in this book of Swedish alcohol policy showed how the country had to adopt to the 
prices and the availability of alcohol, both in order to prevent smuggling and so as not to lose tax revenues. If continental European states should start to legalize cannabis and the prices were attractive, the Nordic countries would find themselves facing the same problems as with the smuggling of alcohol during prohibition or when preventing present-day smuggling of cheap alcohol into the countries. The future drug policies of the Nordic countries will unavoidably be influenced by developments in other European countries.

The attitudes towards using drugs are partly a question of generation. Young people are relatively more liberal. In both Finland and Sweden, the political youth parties are mainly in favour of decriminalization of the use of drugs. This change in attitudes could be linked to an increased awareness of human rights. Such a development is reported from Finland. A drug policy strongly based on penal law will force the police to take action against the young, which will inevitably lead to feelings of injustice among those who are the targets of police interventions. This also links in with the emerging critique of stop and search in several Western countries, which, to a high degree, is justified by the suspicion of the use of drugs. Police practice in the field of drugs becomes intertwined with issues of class and ethnicity, with the potential to challenge politics in wider areas.

The Nordic countries have a tradition of harmonization of penal legislation. As mentioned, this has led to an expansion of penal law in the field of drugs where the countries have referred to each other for the need of strengthening the threat of punishment. At the same time, however, the drug policies of the five countries are partly different, and the political debate might lead to increased differences. Already today, people who have smoked cannabis in Denmark have later been sentenced for the use of drugs in Sweden when traces have been found in urine tests. Apart from the problem of not following the principle of double criminalization, this praxis might cause further strain between the countries if the use of drugs is decriminalized in some countries but could still lead to a sentence in another through the use of drug tests. The tradition of harmonization then might work in the opposite direction. 
All in all, the most likely prognosis is that there will be a change in the drug policy of the Nordic countries. A move in the direction of less use of penal law and criminal justice seems to be unavoidable considering the development in other countries. In addition, the criminal justice approach to drug prevention in the Nordic countries does not seem to have been effective.

In the political debate to target groups that use drugs, two ideal types can possibly be discerned: the user and the abuser. This distinction corresponds to dichotomies used more generally in the analysis of norm-breaking behaviour. Should the deviant be regarded as criminal or sick (Aubert I968), as villain or wretch (Sahlin I994)? That the two categories do not necessarily correspond to a punitive or non-punitive policy has been stressed in this book. The drug user is also alternately pictured as a victim and a perpetrator. The dividing line between these is not clear-cut but rather a continuous variable. Nevertheless, the dichotomy can be used for analytic purposes.

The dependent and marginalized drug consumer who does not seem to gain illegitimately from his or her behaviour would not have to be criminalized. Consumption and the possession of small amounts of drugs for personal use doesn't have to be the concern of the criminal justice system. The drug-abuser could instead be the object of care and treatment, being granted help within a comprehensive public service system. Even the advocates of a zero-tolerance drug policy would today argue for more treatment resources. This is also in line with general welfare state ideology. A public health perspective, which is increasingly being referred to in the Nordic countries, could also justify harm reduction measures but without using that concept.

The question then is what policy a welfare and public health perspective implies for the temporary or recreational user. In the proposal for decriminalization that has been presented to the Norwegian Parliament it is the abuser, not the user, that is the object of the reform. A decriminalization of use and the possession of small amounts, which would be of benefit for the long-time drug-abuser, would legally also apply to the occasional well-adapted drug user. Here, some of the Nordic countries seem to take another stand. The arguments against decriminalization seem to follow two lines. 
The first line of argument is that young people have to be protected. To not decriminalize will then be argued from the perspective of public health. How valid such a line of reasoning is can be discussed. Children who use drugs can be the object of intervention from the social services in the same way as when they use alcohol, which is not illegal. That drug use has been criminalized to such a high extent depends, according to Christie and Bruun (I985), on the fact that it is used by young and powerless people in a way that would not be possible for alcohol consumers. Also an issue here is the effect of a continuous criminalization. When an increasing number of young people are using drugs recreationally there is the risk, if the deterrent effect doesn't work, that the number that will be labelled as criminals will increase. A continued criminalization of drugs, both in the law and in practice, will also pose an increasing risk of creating tensions along age, class and ethnic lines.

The second line of argument is that the users will have to be controlled by criminalization, since they are the cause of drug-abuse, organized crime and deaths. This is the argument in Denmark, where a dual-track system differentiates between those with a problematic use of drugs, who receive help, and the recreational user, who is increasingly criminalized. The argument that the well-adapted user is a pre-requisite for the organized crime and gang-related shootings is increasingly voiced by politicians. In Sweden, the high and rising numbers of drug-related deaths are linked to the policies aimed at preventing first-time drug use. By upholding a zero-tolerance policy and preventing children and young people from using drugs, it is argued - without any empirical support - that fewer people will die from drug use (Proposition 2020/2I:I2I, s. 65). An international quest for a more humanitarian drug policy will, in the Nordic countries, not necessarily change the situation for the recreational user.

The changes in the surrounding world will influence the drug policies of the Nordic countries. The public and political debate have, in just a few years, markedly opened up. Making a retreat is, however, not that easy. Beliefs, ideologies and vested interests can be quite resistant. The Nordic countries stand at a crossroads, but what new roads will be taken is far from clear. 


\section{References}

Aubert, V. (1968). Avvik: Forbrytelse eller sykdom? In J. Israel (Ed.), Sociala avvikelser och social kontroll. Stockholm: Almqvist \& Wiksell. 2 revised ed. upplagan.

Christie, N. \& Bruun, K. (I985). Den gode fiende. Narkotikapolitikk i Norden. Oslo: Universitetsforlaget.

Frantzsen, E. (2005). Narkojakt på gateplan. Om politikontroll av narkotika på Vesterbro. Levert som avhandling til forsvar av doctor juris ved. Københavns Universitet, Juridisk Fakultet, våren.

Gould, A. (1994). Pollution rituals in Sweden: The pursuit of a drug-free society. Scandinavian Journal of Social Welfare, $3(2)$, $8 \mathrm{I}-89$.

Hirdman, Y. (2000). Att lägga livet tillrätta. Studier i svensk folkhemspolitik. Stockholm: Carlssons.

Lappi-Seppälä, T. (20I6). Nordic sentencing. In M. Tonry (Ed.), Sentencing policies and practices in Western Ccuntries: Comparative and cross-national perspectives. Crime and Justice, A Review of Research, vol. 45. Chicago: University of Chicago Press.

Lenke, L. (I99I). Dryckesmönster, nykterhetsrörelser och narkotikapolitik. Sociologisk Forskning, 28(4), 34-44.

Proposition 1987/88:71. Om ändringar i narkotikastrafflagen ( I 968:64). https://data.riksdagen.se/fil/DD I 88367-3C I 7-4755 -8074-oE43677 IEF6D.

Proposition 2020/2I:I32. En förnyad strategi för politiken avseende alkohol, narkotika, tobak och dopning samt spel om pengar $202 \mathrm{I}-2025$. https://www.regeringen.se/49506b/content assets/00420d 7 da29847788a 7 dad65075 ad7d4/prop-2020-2I -I32.pdf.

Rikspolisstyrelsen. (1989). Rakt på knarket. Ett manifest från polisen om kampen mot narkotikabrottsligheten. 2nd edition. Stockholm: Rikspolisstyrelsen.

Sahlin, I. (I994). 'Stackare' eller 'skurk' - om den kluvna klientbilden. Research reports I994:I. Network for Research in 
Criminology and Deviant Behavior at Lund University. Lund: Sociologiska institutionen, Lunds universitet.

Smith P. S. \& Ugelvik, T. (20I7). Punishment and welfare in Scandinavia. In P. Scharff Smith \& T. Ugelvik (Eds.), Scandinavian penal history, culture and prison practice. Embraced by the welfare state? Basingstoke: Palgrave MacMillan.

Svenska Narkotikapolisföreningen, $\underline{\text { SNPF. }}$

Tham, H. (2005). Swedish drug policy and the vision of the good society. Journal of Scandinavian Studies in Criminology and Crime Prevention, 6(I), 57-73.

Westerberg, B. (1994). Reply to Arthur Gould: 'Pollution rituals in Sweden: The pursuit of a drug-free society'. Scandinavian Journal of Social Welfare, 3(3), 94-96. 